\title{
VERB AS OPTATIVITY REPRESENTATION MEANS IN DIFFERENTLY STRUCTURED LANGUAGES
}

\author{
VERBO COMO MEIOS DE REPRESENTAÇÃO DE OPTATIVIDADE EM LÍNGUAS \\ DIFERENTEMENTE ESTRUTURADAS
}

\section{EL VERBO COMO SIGNIFICADO DE REPRESENTACIÓN DE OPTATIVIDAD EN LENGUAS DIFERENTEMENTE ESTRUCTURADAS}

\author{
Dilyara Ilnurovna SHARAPOVA ${ }^{1}$ \\ Ruzilya Rashitovna SALAKHOVA ${ }^{2}$ \\ Gelinya Chayretdinovna GILAZETDINOVA ${ }^{3}$ \\ Aigul Galimzhanovna BOZBAYEVA ${ }^{4}$
}

\begin{abstract}
The article is focused on analyzing the specificity of lexical and grammatical means expressing the optativity semantics in Tatar and English. Examining the matter in question based on pieces of literature explained by a widespread use of optative verbs in fiction as those which are targeted at the sphere exclusively inherent to a person's inner world. The final stage of the study addresses the social and pragmatic substantiation of linguistic peculiarities of the verb vocabulary expressing optative mood in differently structured languages - Tatar and English. Topicality of the study is reasoned by the fact that the verb optative mood category in modern world linguistics is not a subject of a special study at present. The insufficient coverage of the optativity linguistic category primarily initiates a considerable interest in its contrast-comparative study, which is to enable determining the boundaries of grammatical forms and lexical units expressing semantics of wish and identifying their semantic features. Complexity of the study is caused by the point the article addresses an unmediated translation of belles-lettres from English into Tatar being differently structured and genetically unrelated languages, which testified to the study topicality as well.
\end{abstract}

KEYWORDS: Optativity. Desirable mood. Literary translation. Semantics. Tatar. English.

RESUMO: $O$ artigo tem como objetivo analisar a especificidade dos meios lexicais e gramaticais que expressam a semântica da optatividade em tártaro e inglês. $O$ exame do assunto em questão com base em trechos literaturários é explicado por um uso difundido de verbos optativos na ficção, uma vez que são direcionados à esfera exclusivamente inerente ao

1 Kazan Federal University (KPFU), Kazan - Russia. Graduate Student, Institute of Philology and Intercultural Communication. ORCID: https://orcid.org/0000-0002-6660-1074. E-mail: sharapova.dil@mail.ru

2 Kazan Federal University (KPFU), Kazan - Russia. Associate Professor, Institute of Philology and Intercultural Communication. candidate of Philological Sciences. ORCID: https://orcid.org/0000-0003-0947-4264. E-mail: ruzilya5@mail.ru

3 Kazan Federal University (KPFU), Kazan - Russia. Professor, Institute of Philology and Intercultural Communication. Doctor of Philology. ORCID: https://orcid.org/0000-0002-1129-840X. E-mail: ggilaz@mail.ru 4 Mahambet Utemisov West Kazakhstan State University (WKU), Uralsk - Kazakhstan. Associate Professor of the Department of Russian Philology. ORCID: https://orcid.org/0000-0002-9755-5349. E-mail: bozbaeva@mail.ru 
mundo interior de uma pessoa. A fase final do estudo aborda a concretização social e pragmática das peculiaridades linguísticas do vocabulário verbal que expressa o modo optativo em línguas de estrutura diferentes - o tártaro e o inglês. A atualidade do estudo é fundamentada pelo fato de que a categoria do modo optativo verbal na linguística do mundo moderno não é tema de um estudo especial no momento. A cobertura insuficiente da categoria linguística de optatividade inicia principalmente no interesse considerável em seu estudo comparativo de contraste, que é permitir determinar os limites de formas gramaticais e unidades lexicais que expressam a semântica de desejo e identificando suas características semânticas. A complexidade do estudo é causada pelo ponto em que o artigo trata de uma tradução não mediada de belles-lettres do inglês para o tártaro sendo línguas de estrutura diferente e geneticamente não relacionadas, o que também atesta a atualidade do estudo.

PALAVRAS-CHAVE: Optatividade. Humor desejável. Tradução literária. Semântica. Tártaro. Inglês.

RESUMEN: El artículo se centra en analizar la especificidad de los medios léxicos y gramaticales que expresan la semántica de optatividad en tártaro e inglés. Examinar el tema en cuestión a partir de piezas de literatura se explica por un uso generalizado de verbos optativos en la ficción, ya que están dirigidos a la esfera exclusivamente inherente al mundo interior de una persona. La etapa final del estudio aborda la sustanciación social y pragmática de las peculiaridades lingüísticas del vocabulario verbal que expresa el modo optativo en idiomas estructurados de manera diferente: tártaro e inglés. La actualidad del estudio se basa en el hecho de que la categoría de modo optativo del verbo en la lingüistica mundial moderna no es objeto de un estudio especial en la actualidad. La cobertura insuficiente de la categoría lingüistica de la optatividad inicia principalmente un interés considerable en su estudio comparativo de contraste, que es permitir determinar los límites de las formas gramaticales y las unidades léxicas que expresan la semántica del deseo e identificar sus características semánticas. La complejidad del estudio se debe al hecho de que el artículo aborda una traducción no mediada de belles-lettres del inglés al tártaro que tiene una estructura diferente y lenguajes genéticamente no relacionados, lo que también atestigua la actualidad del estudio.

PALABRAS CLAVE: Optatividad. Estado de ánimo deseable. Traducción literária. Semântica. Tártaro. Inglés.

\section{Introduction}

Desirability of the action implementation falls within the area of cognitive research manifested in optativity concept identification determined by certain peculiarities of the world linguistic picture. It is explained by the fact that anthropocentric and system functional areas are leading in modern linguistics, which, in its turn, activates interest in language issues of cultures and intercultural communication.

The study objective is to discover and systematically describe the specificity of translating lexical and grammatical means presenting the optativity semantics in fiction from English to Tatar within the contrast-comparative aspect. To achieve the objective set, the 
following tasks are to be solved: 1) analyze the specificity of translating lexical means expressing the optativity semantics from English into Tatar within the contrast-comparative aspect; 2) analyze the specificity of translating grammatical means expressing the optativity semantics from English to Tatar within the contrast-comparative aspect.

The novel The Adventures of Tom Sawyer by the American writer M. Twain, (TWAIN, 1956). and its translation into Tatar made by S. Ibragimova, Tom Sawyer Mazharalary (TWAIN, 2003). was used as a factual material to examine the issue of optativity in differently structured languages.

The following methods were applied: contrast-comparative analysis, linguistic description, semantic analysis, English into Tatar translation accuracy prediction, and statistical analysis.

Analysis of theoretical sources revealed a considerable number of works examining the word category based on linguistic and private translation studies (KOMISSAROV, 2002 , p. 248), (GABDRAKHMANOVA; NURMUKHAMETOVA; SATTAROVA, 2016, p. 34), (GABDULLAZIYANOVA; NURMUKHAMETOVA; BOLGAROVA, 2018, p. 348).

\section{Results and discussion}

Optativity (Latin "optativus" meaning "desirable") is a linguistic category, a representative of the "wish" concept and a corresponding conceptual category in the language system; it is formed by multilevel language means (YERBULATOVA; GILAZETDINOVA; BOZBAYEVA, 2019, p. 53), (ALTABAEVA, 2003, p. 114). Component and morphological forms of the optativity representatives may differ in different languages. In the modern Tatar language, optativity can be expressed in both component and morphological forms. The following verbs belong to component forms: teley "wish", ashkynu, omtylu "desire”, talpynu "strive”, ometleny "hope”, khyyallannu “dream”.

Morphological forms representing optativity are diverse as well. Thus, the primary means to express the semantics of wish in Tatar is the first person singular and plural verb forms made by adding affixes -yj /-i to the verb stem. Particles and interjections are often used with the form, e.g.: baryjm ele "I'd better go."

Another synthetic form to express the semantics of wish is the verb form ending with gyry/-gere. According to the semantic type, it is attributed to performative optative and expresses an evil wish, a curse. The form is part of affix interjections expressing indignation, e.g.: chanchelgere "(I wish you) fell into something." 
To display the speaker's wish, an analytical verb form ending with - asy kil is employed. It is used with any person and tense, e.g.: maktanasy kile "he/she wants to make boast of something.".

A longing often with a hint of a pipe dream can be expressed applying the following three analytical forms of the verb: 1) the verb form ending with - asy ide; 2) the verb forms ending with -rga/-rge ide; 3) and the verb form ending with -asy iken. For example: elarga ide "I'd rather cry" (TATAR GRAMMAR, 1993, p. 241).

Therefore, the Tatar language presents a considerable number of both lexical and grammatical means expressing the optative semantics. The verb lexemes take a special place among lexical units, while the verb analytical forms prevail within the grammatical means.

English displays more lexical units with optative meaning if compared to Tatar. Thus, verb lexemes form the core of lexical units. These include: to want, to wish (for), to desire, to crave (for/after), to strive, to long (for), to aspire (to/after), to covet, to mean, to pine (for/after), to yearn (for), to hunger (for/after), to hanker (SIBGAEVA; SALAKHOVA; MUKHAMEDOVA, 2017, p. 395).

Having analyzed the novel, The Adventures of Tom Sawyer by M. Twain, 116 English lexemes were found. The main part of these lexemes make verbs; while the verb to want is the most used one (72 items). The verb lexeme to want expresses a neutral wish of a speaker to do something. Predominantly, it was translated into the Tatar language with an analytical verb form ending with -asy kil. For instance, "Oh, you don't want to see!" - "Son bit seznen kyresegez de kilmi!" The forms can be considered completely identical, since the optative semantics is completely preserved in the translated work, and the wish intensity level remains unchanged.

Nouns expressing optative semantics are presented by the following words: wish, desire, lust, passion (for), eagerness, appetite, aspiration, thirst, keenness, vehemence, longing, etc.

In English, to display an intention, such units as mean and intend are employed. Even though equivalent lexemes to transfer the meaning can be found in Tatar, it was translated by means of the verb ending with -asy kil and the lexeme teley: She started homeward, now, intending to find Tom and tell him! - Anyn Tomny ezlep tabyp baryn da sejlep birese kile ide.

There is no optativity indicator in examples where the lexeme to wish was translated into Tatar by means of the verb kyzygu "be interested in, be fond of", e.g.: "Sid wanted to do it, and she wouldn't let Sid." - "Sid ta bi kyzykkan ide ana da rokhset bulmady." Maybe, using such inappropriate lexemes is explained by impossibility to transfer the exact meaning of the 
sentence or its expressiveness if literary translation method is applied. Thus, an adequate translation is enabled.

The adjective group includes such lexemes with optativity semantics as desirable, desirous, eager, anxious (for), acquisitive, aspirational, avid, etc. The only adjective used by the author to express desirability is the lexeme eager ("longing, desirous"). As mentioned above, the adjective as a lexical means expressing the optative semantics is distinguished only in English; therefore, when translating it into Tatar, certain difficulties may arise. Thus, for example, it was translated by a combination of a noun and a preposition - igtibar belən ("with attention, attentively"): Tom lay upon a sofa with an eager auditory about him and told the history of the wonderful adventure, [...]. - Tom-divanga menep yatkan girennen yzlere kyrgen magaralarny igtibar belen tynlauchylarga sejlep yata ide. As there is no such a lexical indicator in the Tatar language, a complete discrepancy of translation is observed.

Grammatical means to express optativity are diverse in English too. Primary grammatical means conveying wish are sentences in the subjunctive mood. They can be conditionally divided into the following groups: infinitive sentences (exclamatory sentences), constructions with the verb wish, constructions with If only, sentences with construction would rather + the past subjunctive and conditional sentences. To express the optative semantics, constructions with wish, if only, would rather and would like, conditional sentences and sentences with the verb hope were used in the novel The Adventures of Tom Sawyer by M. Twain. Constructions with the verb to wish are the most common in the original piece of literature (found in 43 sentences). They are mainly used by the speaker to express improbable or unrealistic desires, often with a shade of regret. Conventionally, six groups can be distinguished according to the method they are translated into Tatar. So, the first group consists of the sentences where the constructions were translated with the verb lexeme YkenY ("regret, repent”), e.g.: "I wish now I'd thought." - "Bu turyda ujlamavym uchen min khezer ykenem." It should be noted that, in the English sentences above, after the verb to wish, the verb past perfect tense form is used, which is applied when the speaker expresses some regret about the past. When translated into Tatar, the semantics is preserved, and tense aspect is not changed, so the forms can be deemed equivalent.

The second group includes verbs in the subjunctive mood, or shartly telek figyl, e.g.: "Somehow, I most wish it was." - "Min anyn toshken buluyn teler idem." In these sentences, the construction with verb wish is identical with the form -yn teler ide. In both the original piece and the translation, the speaker expresses their wish with a touch of an impossible dream and some regret. 
The third and fourth groups include the sentences presenting desirability by means of the verb analytical forms ending with -asy kil- and -asy ide-, respectively: "Don't you wish you were Jeff?" - "Shunyn urynynda bulasy kilmime?” No changes are observed in the sentences. The original semantics of wish is preserved when translated (SUNGATOVA, 2008, p. 129).

The fifth and sixth groups comprise the verb forms in the conditional mood ending with -sa ide without the verb of consequence and the verb form in the imperative mood ending with -sun ide respectively. They are synonymous. For instance, "I wish I could draw." - "Min de shulaj yasyj belsem-ide." It should be noted that the construction to wish + could expresses a desire directed to the future, while the construction to wish + had expresses a desire directed to the present; both the constructions were translated into Tatar with the verb form ending with sa ide and the verb form ending with -sun ide, which do not reflect the tense aspect. It is primarily due to the fact that in the Tatar language these forms do not convey the tense aspect.

The translation of the conditional sentences into Tatar is considered to be one of the most accurate and well-executed as it was done using forms of the same conditional mood, e.g.: "What if he went away?" - "Serle gene reveshte yukka chyksa ide." The optative semantics in the sentences above remains identical. The construction If + will included in the same group is translated into Tatar employing the verb analytic form ending with -asy kil- in the conditional mood form, i.e. a complete correspondence between both the formal-structural and semantic functions of the grammatical means can be observed.

Only two sentences in M. Twain's novel were translated into Tatar using the first person plural verb form (-yj, i). As, according to many researchers (SUNGATOVA, 2008: 129), (YUISUFUVA et al., 2016: 164), (GABDRAKHMANOVA et al., 2019, p. 5), expressing desirability in the Tatar language has been preserved in that form only. The sentences incorporate the construction hope (that) + Future Simple, e.g.: "But I hope we won't get lost." - "Yakhshy lekin adasha kyrmik"; and the construction would like, e.g.: "I'd like to see her get around this with her rubbage "bout superstition." - "Karap-karyjk shunnan son da imeshmimeshlerge yshanyrga yaramyj dip ejter miken.” The constructions are employed to express the speaker's wish, but the semantics of wishing is shifted into the background. While the semantics of hope is more manifested in the first sentence, the semantics of preference is displayed in the second one.

As part of the study, it was revealed that a considerable number of lexical units were used to express the semantics of wish in the original work, among which the verb being the dominant one. Most translation cases are considered to be well executed. Although, there are frequent examples with partial or complete translation mismatching, which is primarily 
explained by absence of equivalent forms in Tatar. Grammatical means are very diverse too. In Tatar, synthetic and analytical verb forms for the speaker to express wishing can be distinguished. The most frequently used one is the verb stem + affixes - yj / - i of the verb forms ending with -asy kil, -asy-ide, -rga/-rge ide. In English, sentences in the subjunctive mood occupy a significant segment, among which the most often employed are constructions with the verb to wish and construction if only. Most grammatical tools are unique to each language.

Thus, the analysis process exposed that the translation of grammatical means can be considered more well executed than the translation of lexical units as, when translating the grammatical constructions from the original language into the target one, they are replaced by identical structures in most cases. By the way of illustration: constructions with the verb to wish were translated into Tatar by using the verb lexeme Ykeny ("regret, repent"), the verb forms in the subjunctive mood, the conditional mood ending with -sa ide without the verb of consequence and the imperative mood ending with -sun id, as well as the verb analytic forms ending with -asy kil and -asy ide. Despite various means of translating the same construction, all of them should be deemed correct and each translation case can be considered adequate and identical, as, when transmitted into Tatar, their semantics of wishing was completely preserved (at that, the semantics of regret was preserved too), as well as their intensity and tense aspect. Thus, for instance, conditional sentences were translated from English into Tatar using forms of the same conditional mood, at that, the semantics of wish remained identical. The translation of lexical means is considered less precise as there are quite many examples when the wish intensity was decreased, its semantics altered and the translation was completely inconsistent. For example, the most frequently used unit to want was translated into Tatar by means of the verb analytical form ending with -asy kil, the lexeme teley ("want"), the verb form ending with -makchy ide, units kirek ("needed, necessary”), kuzugy (“be interested in, be fond of") and koty ("wait"). While the first two translation variants are considered equivalent (the semantics of wish and its intensity remains unchanged), yet, in the next three translation forms, the optative semantics is displayed at the second level with its intensity much reduced (due to employing specific concepts: wish-intention, wish-necessity, and wish-hope), and the last two variants can be deemed completely inappropriate. Moreover, there are examples completely omitting the original units: the semantics of wish is not displayed at all when translated. 


\section{Summary}

Direct translations from the original language are rather rare, which makes the translated novel The Adventures of Tom Sawyer by M. Twain a rather prominent one. The study analyzed the specificity of translating lexical and grammatical means expressing semantics of wish from English into Tatar, and its results revealed that the semantics of wish in Tatar and English can be presented via different lexical and grammatical means. The lexical means expressing wish in both languages are represented by numerous units, and almost all parts of speech. Such parts of speech as the verb, the noun, the adverb, and the participle are considered to be universal for both languages. Adverbial participles are deemed to be unique for Tatar, while adjectives are peculiar for English. Verbs are the core of all lexical units. They are numerous in Tatar and English alike. However, the English language is distinguished by a larger variety of lexemes conveying semantics of wish, when compared to Tatar.

\section{Conclusion}

Preference to one verb expressing wish is not observed in pieces of literature. Verbs denoting wish are numerous in fiction as their accumulation through repetition serves as a marker of a character's vitality. Therefore, it is reasonable to study other optativity forms namely based on belles-lettres material.

ACKNOWLEDGEMENTS: The work is performed according to the Russian Government Program of Competitive Growth of Kazan Federal University.

\section{REFERENCES}

ALTABAEVA, E.V. Optive sentences in modern Russian: a textbook. Michurinsk, 2003. $164 \mathrm{p}$.

GABDRAKHMANOVA, F. H.; NURMUKHAMETOVA, R. S.; SATTAROVA, M. R. Peculiarities of transmission of American culture in Russian translated texts. Modern Journal of Language Teaching Methods, n. esp., p. 32-36, 2016.

GABDRAKHMANOVA, F. H.; ZAMALETDINOVA, G. F.; ZAMALETDINOV, R. R.; SATTAROVA, M. R. The national-cultural values of the Tatars in paremies with lexemas "oy / yort” (house)". Revista Turismo Estudos \& Práticas (RTEP), v. 8, n. 1, p. 1-7, 2019.

GABDULLAZIYANOVA, G. I.; NURMUKHAMETOVA, R. S.; BOLGAROVA, R. M. Etymological Dictionary of the Tatar Language as the Source of Turkic Language Vocabulary 
Comparative Study. Modern journal of language teaching methods, v. 8, n. 11, p. 346-351, 2018.

KOBRIN, N. A. English grammar: morphology. St. Petersburg: Soyuz Publishing House; Lenizdat, 2000. 496 p.

KOMISSAROV, V. N. Modern translation: a training manual. Moscow: ETS., 2002. 424 p.

SIBGAEVA, F. R.; SALAKHOVA, R. R.; MUKHAMEDOVA, S. Representation of person emotional state in the Tatar Language picture of the world. AD ALTA: Journal of interdisciplinary Researc, v.7, p. 260-262, 2017.

SUNGATOVA, G. F. Desirable mood in the Turkic literary monuments of the XIV century. Scientific notes of Kazan University. Series Humanities, n. 8, p. 128-134, 2008.

TATAR grammar. Tatar book. 3 volumes. Kazan: Publishing House, 1993. T. II, 397 p.

TWAIN, M. The adventures of Tom Sawyer: the adventures of huckleberry finn: a novels. Moscow: Foreign lang. publ. house, 1956. 575 p.

YERBULATOVA, I. K.; GILAZETDINOVA, G. K. H.; BOZBAYEVA, A. G. Peculiarities of translation of kazakh realities with a cultural historical component of meaning.

International Journal of Higher Education, v. 8, p. 51-54. 2019.

YUISUFUVA, Z. et al. Paroemiological units of the tatar language with culture-specific.

Modern Journal of Language Teaching Methods, n. esp., p. 161-165, 2016.

TWAIN, M. Tom Sojer magaralary: roman. Kazan: Megarif. 2003. 271 p.

\section{How to reference this article}

SHARAPOVA, D. I.; SALAKHOVA, R. R.; GILAZETDINOVA, G. C.; BOZBAYEVA, A. G. Verb as optativity representation means in differently structured languages. Rev. EntreLínguas, Araraquara, v. 7, n. esp. 1, p. 223-231, fev. 2021. e-ISSN: 2447-3529. DOI: https://doi.org/10.29051/el.v7iEsp1.14891

Submitted: $28 / 10 / 2020$

Required revisions: $19 / 12 / 2020$

Approved: 13/01/2021

Published: 28/02/2021 